\title{
Recent distribution of Sphaerium nucleus (Studer, 1820) (Bivalvia: Sphaeriidae) in the Czech Republic
}

\author{
Tereza KořínKová ${ }^{1}$, Luboš Beran ${ }^{2} \&$ Michal Horsák ${ }^{3}$ \\ 'Department of Zoology, Charles University, Viničná 7, Praha 2, CZ-12844, Czech Republic, e-mail: korinko1@natur.cuni.cz \\ ${ }^{2}$ Kokořinsko PLA Administration, Česká 149, Mělník, CZ-27601, Czech Republic, e-mail lubos.beran@nature.cz \\ ${ }^{3}$ Department of Botany and Zoology, Masaryk University, Kotlářská 2, Brno, CZ-61137, Czech Republic; \\ e-mail:horsak@sci.muni.cz
}

KořínKová T., Beran L. \& Horsák M., 2008: Recent distribution of Sphaerium nucleus (Studer, 1820) (Bivalvia: Sphaeriidae) in the Czech Republic. - Malacologica Bohemoslovaca, 7: 26-32. Online serial at $<$ http://mollusca. sav.sk> 3-Apr-2008.

\begin{abstract}
Recent data about the distribution of Sphaerium nucleus in the Czech Republic are summarized and used in an attempt to evaluate its conservation status. During the last ten years, this species was found at 40 sites, mostly shallow small water bodies situated in lowland river alluviums. These types of habitats are generally endangered due to the huge human impact and exploration of these areas. The revision of voucher specimens of Sphaerium corneum s.lat. deposited in museum collections yielded a further 22 old records of $S$. nucleus
\end{abstract}

Key words: Sphaerium nucleus, distribution, molluscan assemblages, habitats, threats

\section{Introduction}

In the last two decades, research on sibling species complexes has been widely involved in taxonomy and distribution of freshwater molluscs. Some groups of closely related species possess reliable characters only on their reproductive organs, e.g. the structure of male genitalia in "Stagnicola palustris agg." (O.F. Müller, 1774) (JACKIEwICZ 1993). However, using molecular data one species of this complex - i.e. S. turricula (Held, 1836), previously recognized on the basis of anatomical characters, were found not to be independent from S. palustris s.str. (O.F. Müller, 1774) (BArgues et al. 2001, 2005). There are also several examples in the case of freshwater clams; the structure of gills and shell porosity were successfully used to distinguish Pisidium globulare (Clessin, 1873) as a separate species from Pisidium casertanum (Poli, 1791) (KorNiushin 1998, 1999). Valid species were recently also found in the "Sphaerium corneum agg." (Linnaeus, 1758) (Korniushin 1996, 2001). The taxonomic status of one of these species, i.e. Sphaerium nucleus (Studer, 1820), and its distinctness from the morphologically similar S. corneum (Linnaeus, 1758) has been recently supported by both anatomical and molecular studies (KoRNIUSHIN 1996, 2001, KoŘínKOvÁ et al. in prep.). Furthermore, these two species differ in their ecology - the former species inhabits almost exclusively small periodical waters and thus its conservation status was a point of discussion. Since $S$. nucleus was first found at two sites in the Czech Republic in 2003 (KoŘínKOVÁ 2006), it was considered likely that many populations from suitable habitats originally determined as $S$. corneum could in fact belong to $S$. nucleus. The discovery of new sites for $S$. nucleus could also be expected.
The aim of this paper is to summarize all known records of $S$. nucleus in the Czech Republic based on both results of current field researches and revisions of collection materials.

\section{Material and methods}

From 2003 to 2007, living animals and empty shells were collected from the habitats favourable for S. nucleus, using bowl-shaped sieve. The choice of collection sites was made according to the description of habitats published by FALKNER (2000), Mildner (2001), and KorNiUSHIN (2001). Some populations were also discovered within the scope of other field studies, namely faunistic mapping of molluscs in the Czech Republic. Animals were killed in carbonated water and then conserved in $70 \%$ ethanol for anatomical studies. Most of the samples were determined or revised by T. Kořínková. Shape of kidney, shell porosity and arrangement of muscle scars were used as the main identification characters (KořínKOvÁ 2006 - only specimens bearing at least two of the characters typical for $S$. nucleus were considered for the study). Other species on the collection sites were also recorded. Available voucher specimens of $S$. corneum s.lat. deposited in museum or private collections were also re-examined (i.e. collection of J. Brabenec, National Museum in Prague; coll. S. Mácha, Silesian Regional Museum in Opava; coll. M. Horsák in Brno).

\section{Results}

In the course of this study 40 recent (i.e. not older than 10 years) records of Sphaerium nucleus have been made in 17 mapping grids of the Czech Republic (Fig. 1). Using only recent records, i.e. those collected by the authors 


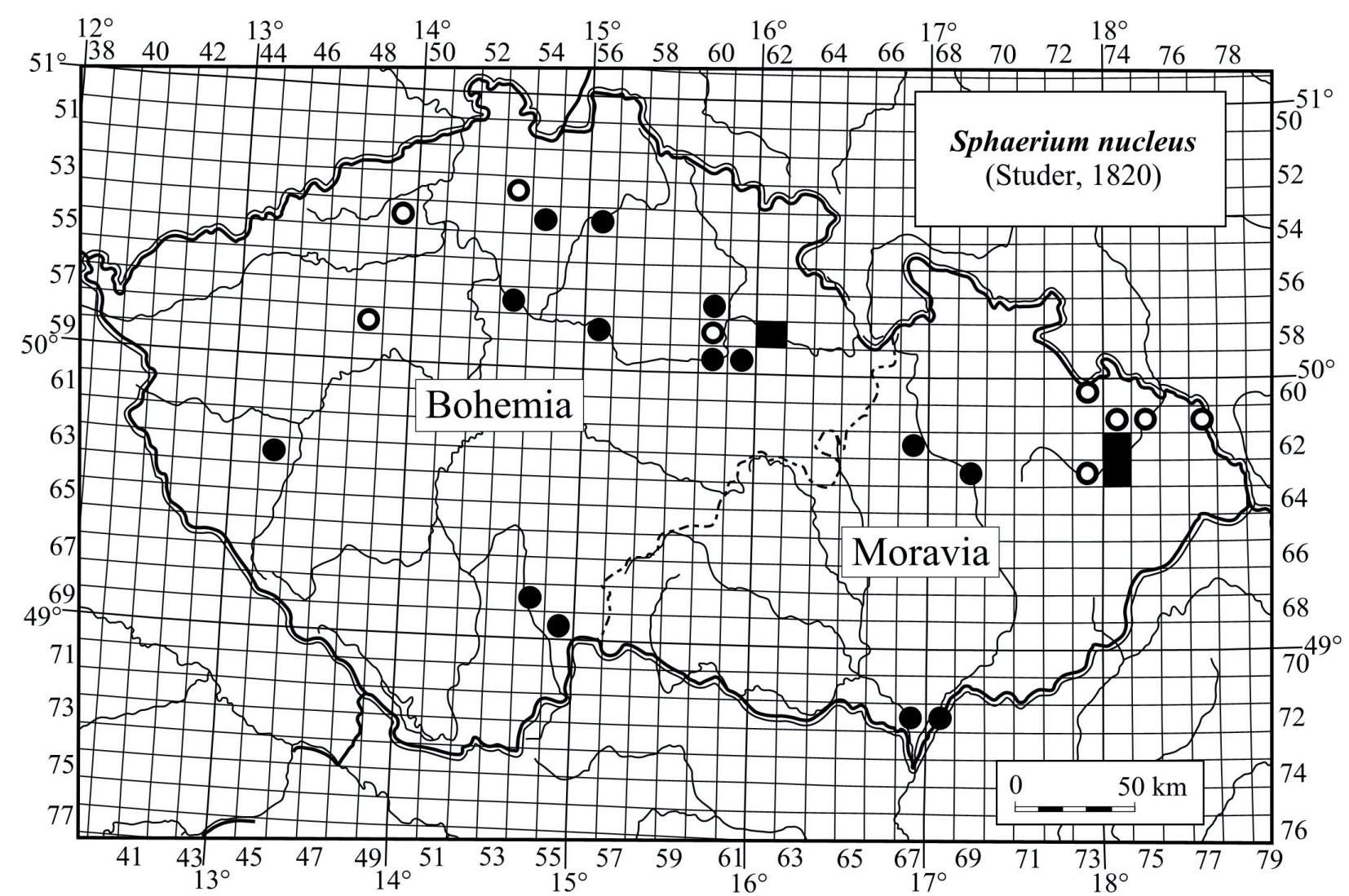

Fig. 1. Distribution of Sphaerium nucleus in the Czech Republic (full dots - recent data from 1996-2007, empty dots - data from revised collections, squares - both recent and historical data).

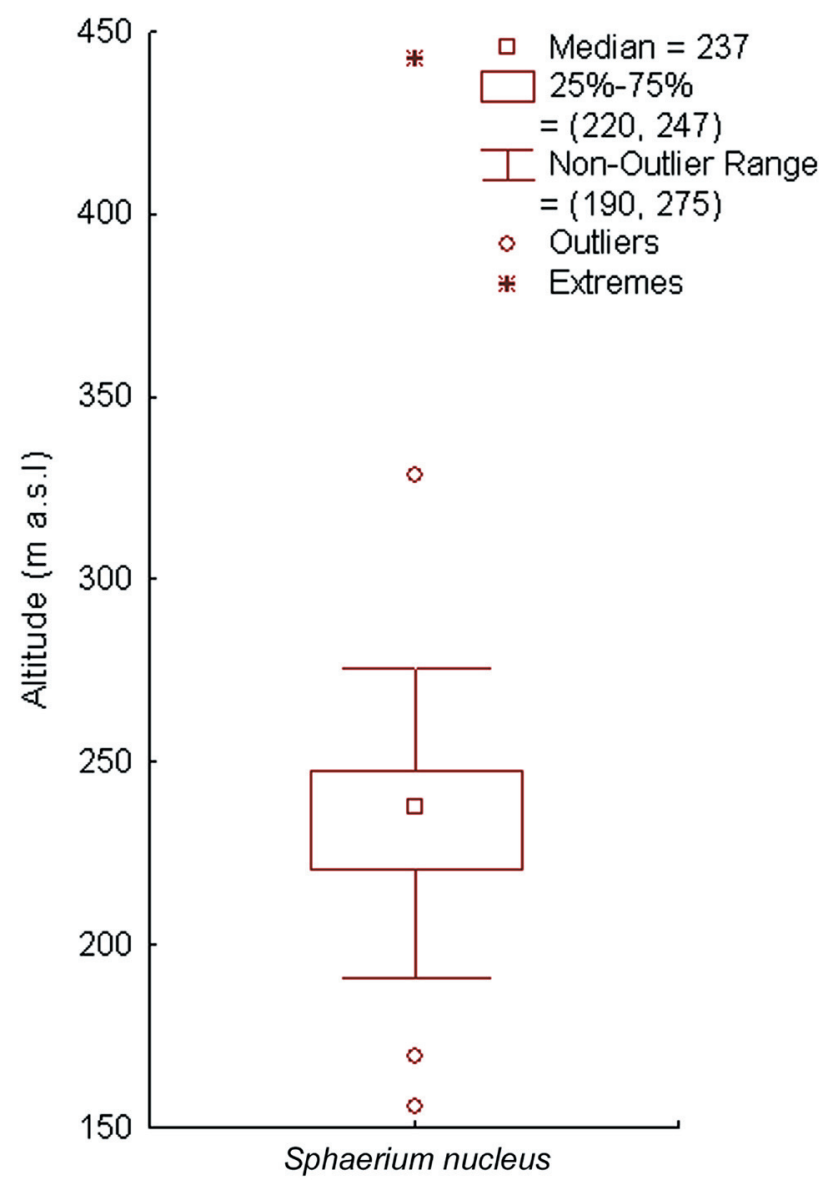

Fig. 2. Altitude range of sites with occurrence of Sphaerium nucleus. of this paper, we obtained reliable data about the species ecology. The species inhabits presumably small and often periodical pools, littoral zones of ponds, shallow swamps and drains with stagnant water and dense vegetation. The altitude of the species sites ranged from 155 to $442 \mathrm{~m}$ a.s.l. (see Fig. 2). The molluscan assemblages of the habitats where $S$. nucleus was found proved to be relatively consistent in species composition, characterized by Planorbis planorbis (Linnaeus, 1758), Anisus vortex (Linnaeus, 1758), Stagnicola palustris (O.F. Müller, 1774), Planorbarius corneus (Linnaeus, 1758), Valvata cristata (O.F. Müller, 1774), Segmentina nitida (O.F. Müller, 1774), and Bathyomphalus contortus (Linnaeus, 1758), which co-occurred at more than half of the target sites (Fig. 3, Tab. 1). Sphaerium nucleus also co-occurred at the majority of recent sites with populations of rare and highly threatened species Anisus vorticulus (Troschel, 1834) (9 sites) and Pisidium pseudosphaerium (Favre, 1927) (10 sites).

No recent co-occurrence of $S$. corneum and $S$. nucleus in the same habitat has been observed. In a few cases, both species were found in the same sample in the voucher material from studied museum collections. However, those samples could come from fluvial deposits or have been probably collected in two different water bodies lying not far apart.

\section{Discussion}

On the basis of recent field researches as well as the revision of voucher museum lots we confirmed that Sphaerium nucleus is distributed throughout the Czech Republic lowlands (Fig. 2). S. nucleus seems to be a typical inha- 


$$
\text { L }
$$




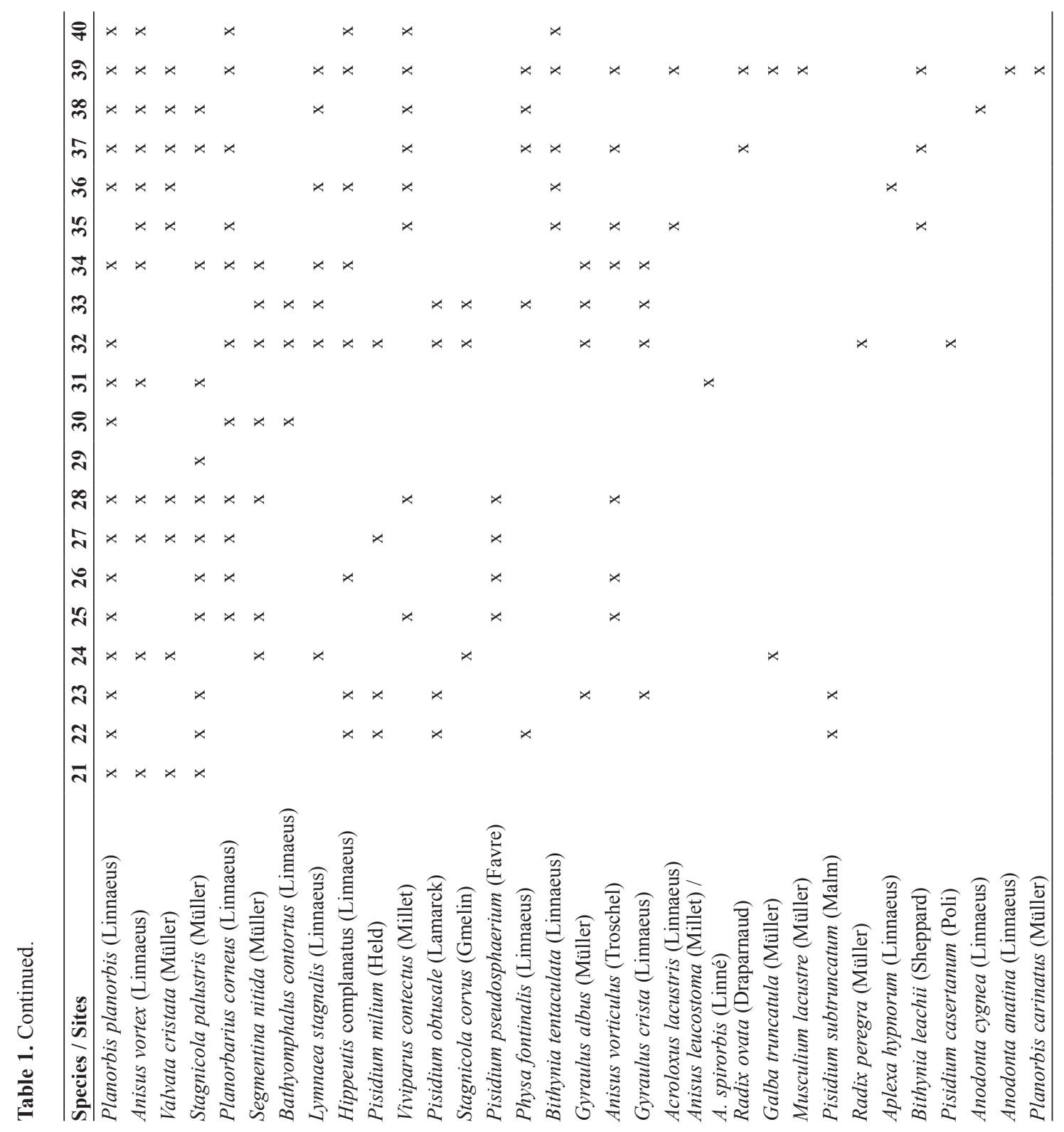


bitant of small stagnant and periodical waters presumably in lowland river alluviums. This is quite in accordance with findings of previous authors (FALKNER 2000, MILDNER 2000, KorniUshin 2001, Zettler \& GlÖER 2006). Regarding the different habitat preferences of $S$. nucleus and its ecologically euryvalent sibling species $S$. corneum, any future findings of both species in the same water body would be of interest, however, in that case, the species could be assumed to inhabit different microhabitats. More attention should be also paid to the possible occurrence of $S$. ovale, which is not rare in the neighbouring countries - this species rather prefers running waters (ZETTLER \& GLÖER 2006, GLÖER 2006, P. GLÖER pers. comm.).The co-occurrence of S. nucleus, Anisus vorticulus, Pisidium pseudosphaerium, and $P$. globulare has already been reported (FALKNER 2000, KoŘínKOVÁ 2006), but the present study gives a more comprehensive overview of the molluscan assemblages in these types of habitats. Bithynia leachii (Sheppard, 1823), Anisus vorticulus, Pisidium pseudosphaerium and P. globulare co-occurring with $S$. nucleus are classified according to IUCN classification in the Red List of the Czech molluscs (BERAN et al. 2005) as critically endangered (CR). Planorbis carinatus O.F. Müller, 1774 is classified as endangered and Viviparus contectus (Millet, 1813), Anisus spirorbis (Linnaeus, 1758), Segmentina nitida, Anodonta cygnea (Linnaeus, 1758), and Pisidium hibernicum Westerlund, 1894 as vulnerable (VU). S. nucleus itself is considered endangered (EN) by authors of the Red List (BERAN et al. 2005) and this classification is in accordance with our results. We found that the most important threats of this species are destruction of suitable habitats and substantial negative man-made changes (e.g. drainage, eutrophication, succession changes, etc.).

\section{Acknowledgements}

The research and manuscript preparation were also supported by the long-term research plans of Masaryk University (Czech Ministery of Education, MSM 0021622416). The authors would also like to express their thanks to K. Neumannová (National Museum, Praha) and M. Gajdošík (Silesian Regional Museum Opava) for enabling access to museum collections.

\section{References}

Bargues M.D., Vigo M., Horak P., Dvorak J., Patzner R.A., Pointier J.P., Jackiewicz M., Meier-Brook C. \& Mas-Coma S., 2001: European Lymnaeidae (Mollusca: Gastropoda), intermediate hosts of trematodiases, based on nuclear ribosomal DNA ITS-2 sequences. - Infection, Genetics and Evolution, 1: 85-107.

Bargues M.D., Artigas P., Jackiewicz M., Pointier J.P. \& Mas-COMA S., 2005: Ribosomal DNA ITS-1 sequence analysis of European Stagnicoline Lymnaeidae (Gastropoda). - Heldia, 6(1/2): 57-68.

Beran L. \& Horsák M., 1998: Aquatic molluscs (Gastropoda, Bivalvia) of the Dolnomoravský úval lowland, Czech Republic. - Acta Soc. Zool. Bohem., 62: 7-23.

BERAN L., 2006: Vodní měkkýši PR Žernov ve východních Čechách [Aquatic molluscs of the Žernov Nature Reserve in Eastern Bohemia (Czech Republic)]. - Vč. sb. př́r. Práce a studie, 13: 245-247.

BERAN L., 2007a: Vodní měkkýši národní přírodní rezervace Libický luh. [Aquatic molluscs of the National Nature Reserve]. - Acta Musei Reginaehradensis s.a., 32: 43-52.

Beran L., 2007b: Vodní měkkýši PP Častava a PR Plané loučky v CHKO Litovelské Pomoraví (stř̌ední Morava). [Aquatic molluscs of the Častava Nature Monument and the Plané loučky Nature Reserve in the Litovelské Pomoraví PLA (Central

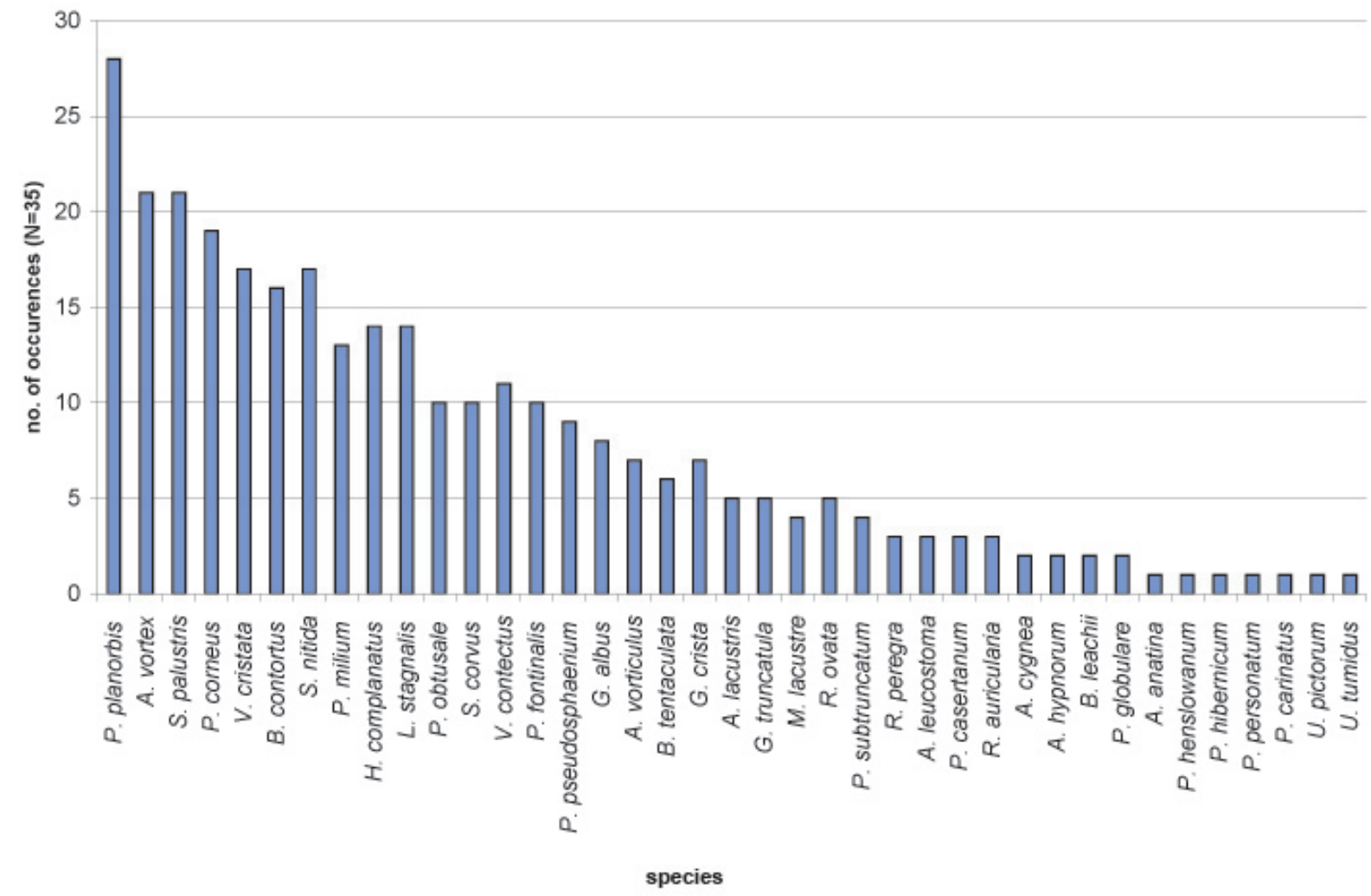

Fig. 3. Numbers of co-occurrences of individual species with Sphaerium nucleus. Constructed based on data shown in Table 1 (only recent data). 
Moravia, Czech Republic)]. - Zprávy Vlastivědného muzea v Olomouci, č. 294: 76-85.

BERAN L., 2007c: Vodní měkkýši přírodní rezervace Všetatská černava. [Aquatic molluscs of the Všetatská černava Nature Reserve (Central Bohemia, Czech Republic)]. - Bohemia centralis, Praha, 28: 377-381.

BERAN L., 2007d: Vodní měkkýši rybníků v PR U Houkvice (východní Čechy, Česká republika). [Aquatic molluscs of the U Houkvice Nature Reserve (Eastern Bohemia, Czech Republic)] - Vč. sb. přír. Práce a studie, 14: 207-211.

Beran L., JuŘIČKová L. \& Horsák M., 2005: Měkkýši (Mollusca). - In: Červený seznam ohrožených druhů České republiky. Bezobratlí [Red list of threatened species in the Czech Republic. Invertebrates], FARKaČ J., Král D. \& ŠKorpíK M. (eds) AOPK, Praha, pp. 69-74.

FALKNER G., 2000: Sphaerium (Nucleocyclas) nucleus in Bayern. - Heldia 3(1): 11-18.

GLÖER P., 2006: Der Gefährdungsgrad der Sphaeriidae (Bivalvia, Veneroida) in Hamburg. - Basteria, Supplement, 3: 29-37.

Horsák M., 2000a: První nález Anisus vorticulus (Troschel, 1834) v CHKO Poodři [The first record of Anisus vorticulus (Troschel, 1834) in the Poodří Protected Landscape Area]. - Čas. Slez. Muz. Opava (A), 49: 95-96.

HoRsÁK M., 2000b: Měkkýši (Mollusca) navrhované NPR Oderský luh v CHKO Poodří (Česká republika) [The molluscs of the Oderský luh proposed National Nature Reserve in the Poodř́ Protected Landscape Area (Czech Republic)]. - Čas. Slez. Muz. Opava (A) 49: 183-187.

Horsák M. \& Neumanová K., 2004: Distribution of Pisidium globulare Clessin, 1873 (Mollusca: Bivalvia) in the Czech Republic and Slovakia with notes to its ecology and morphological characters. - Journal of Conchology 38(4): 373-381.

JACKIEWICZ M., 1993: Phylogeny and relationship within the European species of the family Lymnaeidae. - Folia Malacologica, 5: 61-95.

KornUishin A.V., 1996: [Bivalve molluscs of the superfamily Pisidioidea in the palearctic region. Kiev: Schmalhausen Institute of Zoology], 175 pp. (in Russian, English summary)

Kornuishin A.V., 1998: On the identity of the anatomically distinct form of Pisidium casertanum (Poli) $(=$ P. roseum sensu Korniushin 1995). - Heldia, 2: 133-135.

KorNUISHIN A.V., 1999: Anatomical investigation and taxonomic revision of pill clams of the genus Pisidium s.l. (Bivalvia: Sphaeriidae) in the Palearctic region. - Malacological Review, Suppl. 8: 31-36.

KorNIUSHIN A.V., 2001: Taxonomic revision of the genus Sphaerium s.l. in the Palaearctic region, with some notes on the North American species. - Arch. Moll., 129: 77-122.

KoŘínKOVÁ T., 2006: The first reliable records of Sphaerium nucleus (Mollusca: Bivalvia: Sphaeriidae) in the Czech Republic. - Acta Soc. Zool. Boh., 69: 293-297.

KoŘínKová T., Petrusek A. \& JuŘičKová L., in prep: Application of combined methodological approach to the case of two closely related species of fingernail clams.

Mildner P., 2001: Bemerkungen zur Faunistik der Sphaeriidae Karntens. - Carinthia, 112: 437-447.

Pruner L. \& Míka P., 1996: Seznam obcí a jejich částí v České republice s čísly mapových polí pro sítové mapování fauny [List of settlements in the Czech Republic with associated map field codes for faunistic grid mapping system]. - Klapalekiana, 32 (Suppl.): 1-175

ZettLer M.L. \& GlÖER P., 2006: Zur Ökologie und Morphologie der Sphaeriidae der Norddeutschen Tiefebene. - Heldia, 6(8): 1-61; pl. 1-18.
Appendix 1. Survey of known recent sites of Sphaerium nucleus in the Czech Republic. Data in the list are as follows: number of the site, geographical co-ordinates (N, E) (Geobáze digital map of the Czech Republic 1:100,000), code of the mapping grid for faunistic mapping according to PRUNER \& Míka (1996), name of the nearest settlement, elevation ( $\mathrm{m}$ a.s.l., approximately), description of the site, number of individuals (ex.), date of investigation, name of investigator (LB - Luboš Beran; MH - Michal Horsák; TK - Tereza Kořínková). References of already published records are given.

1 - 50³5'04", 1443'10", 5454, Břehyně, 275 m, Břehyně - Pecopala Nature Reserve, a fen littoral on the northern side of Břehyñský rybník Pond, 650 m north-east of the Mlýnský vrch Hill, 9 ex. 18.10.2005, MH; 2 - 50³2'44", 1503'08", Březina, 5456, 237 $\mathrm{m}$, an overshadowed muddy and shallow (depth $10-15 \mathrm{~cm}$ ) edge of the Žabakor Pond to the east of the village, 15 ex., 4.6.2005, LB; 3 - 50 $0^{\circ} 16^{\prime} 29^{\prime \prime}, 14^{\circ} 34^{\prime} 23^{\prime \prime}, 5753$, Všetaty, $169 \mathrm{~m}$, a shallow (depth 10-20 cm), small and temporary pool (overshadowed without vegetation) in the Všetatská černava Nature Reserve, 6 ex., 9.4.2004, LB, (Beran 2007c); 4 - 50¹5'24", 1540'50", 5760 , Popovice, $250 \mathrm{~m}$, a shallow (depth $5-15 \mathrm{~cm}$ ) wetland near the Bystřice River near Popovice, a) 35 ex., 31.5.2003, LB, b) 20 ex., 23.6.2005, TK; 5 - 5007'11", $15^{\circ} 09^{\prime} 42^{\prime \prime}, 5856$, Libice nad Cidlinou, $190 \mathrm{~m}$, a shallow (depth 10-20 cm) overgrown edge of the pool in the northern head of the Libický luh National Nature Reserve, 4 ex., 23.4.2005, LB, (BERAN 2007a); 6 - 5006'45", 1509'34", 5856, Libice nad Cidlinou, $191 \mathrm{~m}$, a large and shallow (depth 10-15 cm) Glyceria maxima swamp in the Libický luh National Nature Reserve, 3 ex., 24.9.2005, LB, (Beran 2007a); 7 - 5005'41", 15³9'43", 5862, Petrovice, 243 $\mathrm{m}$, a shallow (depth 10-25 cm) edge of the Malá Houkvice Pond in the U Houkvice Nature Reserve, 12 ex., 26.8.2006, LB, (BERAN 2007d); 8 - 5005'32", 15³9'41", 5960, Lázně Bohdaneč, $218 \mathrm{~m}$, shallow (depth 10-25 cm) Glyceria maxima swamp and reeds along the western bank of the Bohdanečský rybník Pond, $200 \mathrm{~m}$ north from the dam, 20 ex., 2.7.2006, LB; 9 - 50 $05^{\prime} 41 "$ ", 15³9'43", 5960, Lázně Bohdaneč, $218 \mathrm{~m}$, shallow (depth 10-25 $\mathrm{cm})$ Glyceria maxima swamp and reeds along the western bank of the Bohdanečský rybník Pond 300-400 m north from the dam, 10 ex., 2.7.2006, LB; 10 - 5005'44", 15³9'50", 5960, Lázně Bohdaneč, $218 \mathrm{~m}$, shallow (depth 10-20 cm) swamps and pools in the north-western bay of the Bohdanečský rybník Pond, 5 ex., 2.7.2006, LB; 11 - 5005'27", 1556'58", 5961, Horní Ředice, $237 \mathrm{~m}$, shallow (depth 10-25 cm) sedge marshes on the northwestern edge of the Mordýr Pond, 2 ex., 23.4.2005, LB, (BERAN 2006); 12 - 49 42'18", 1804'44", 6274, Studénka, 240 m, a meadow pool near the north-east edge of the Kotvice Pond, 5 ex., 3.9.1999, MH and P. Kment, originally published as S. corneum (Horsák 2000a, Horsák \& NeUMANOvÁ 2004), 7 ex. 21.10.2007;

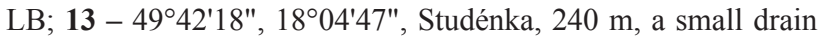
near north-east edge of the Kotvice Pond close to a former railway-track, 40 ex., 21.10.2007, LB; $14-49^{\circ} 42^{\prime} 16^{\prime \prime}, 1^{\circ} 04^{\prime} 39^{\prime \prime}$, Studénka, $240 \mathrm{~m}$, a temporary meadow swamp near the north edge of the Kotvice Pond (depth ca $10 \mathrm{~cm}$ ), a dense vegetation cover, 7 ex., 21.10.2007, LB; 15 - 49 42'21", 1804'57", 6274, Studénka, $240 \mathrm{~m}$, a meadow pool near the north-western edge of the Kotvice Pond, a) 20 ex., 3.9.1999, MH and P. Kment, originally published as $S$. corneum (Horsák 2000a, Horsák \& NeUMANOVÁ 2004), b) 21.10.2007, LB; 16 - 4943'14", 1806'44", 6274, Studénka, $235 \mathrm{~m}$, a flood-plain forest of Bažantnice, 38 ex., 16.9.1996, MH, originally published as $S$. corneum (Horsák 2000b); 17 - 4942'44", 1805'23", 6274, Studénka, 235 m, lowlands near the south-eastern edge of the Nový rybník Pond, 50 ex., 2.9.1999, MH; 18 - 49 42'23", 1805'15", 6274, Studénka, $239 \mathrm{~m}$, a small drain (width $0.5 \mathrm{~m}$, depth $0.5 \mathrm{~m}$ ) with slowly running water and muddy bottom, partly covered with water plants, near the Kačák Pond ca. 1.5 km south-east of Studénka, 
30.7.2003, TK; 19 - 49 $42^{\prime} 03^{\prime \prime}, 18^{\circ} 04^{\prime} 40^{\prime \prime}, 6274$, Studénka, 239 $\mathrm{m}$, a shallow (depth 10-25 cm) edge of the Kotvice Pond near the dam of the Nový rybník Pond, 15 ex., 13.9.2006, LB; 20 - 49 40'45", 1801'48", 6374, Bartošovice, $247 \mathrm{~m}$, pools and swamps between Dolní and Horní Bartošovický rybník Ponds near the south-western edge of the Dolní Bartošovický rybník Pond, 10 ex., 13.9.2006, LB; 21 - 49 40'35", 1801'48", 6374, Bartošovice, $247 \mathrm{~m}$, temporary sedge marshes near the pool to the south of the dam of the Horní Bartošovický rybník Pond, 9 ex., 14.9.2006, LB; 22 - 49³9'28", 1314'35", 6345, Vodní Újezd, $328 \mathrm{~m}$, shallow (depth 10-25 cm) sedge marshes to the west of Vodní Újezd, 4 ex., 25.6.2005, LB; 23 - 49³9'27", 13¹4'33", 6345, Vodní Újezd, $328 \mathrm{~m}$, shallow (depth 10-25 cm) edges of overshadowed pools in forest to the west of Vodní Újezd, 10 ex., 25.6.2005, LB; 24 - 4945'04", 1659'47", 6267, Moravičany, $280 \mathrm{~m}$, small pools (max. depth $0.7 \mathrm{~m}$ ) with dense vegetation cover near the railway ca. $1.5 \mathrm{~km}$ east of Moravičany, Jul 2005, TK; 25 - 49 $37^{\circ} 25^{\prime \prime}, 17^{\circ} 13^{\prime} 54^{\prime \prime}, 6369$, Horka na Moravou, 220 $\mathrm{m}$, the Izákova tůn̆ Pool in the western part of the Plané loučky Nature Reserve, a) 18 ex., 4.10.2003, LB, (BERAN 2007b), b) 10 ex., 15.5.2004, LB, (BERAN 2007b); 26 - 49³7'24", 17¹3'55", 6369, Horka na Moravou, $220 \mathrm{~m}$, the Jelito Pool in the western part of the Plané loučky Nature Reserve, 13 ex., a) 4.10.2003, LB, (Beran 2007b), b) 15.5.2004, LB, (Beran 2007b); 27-

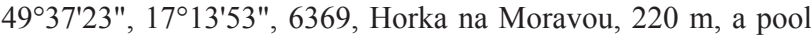
in the northern edge of the Velká rákosina Swamp in the Plané loučky Nature Reserve, 17 ex., 4.10.2003, LB, (BERAN 2007b); 28 - 49 $37^{\prime} 18^{\prime \prime}, 17^{\circ} 13^{\prime} 55^{\prime \prime}, 6369$, Horka na Moravou, $220 \mathrm{~m}$, the Rákosová tůn̆ Pool in the central part of the Plané loučky Nature Reserve, 7 ex., 18.10.2004, LB, (BERAn 2007b); 29 - 49³7'16", 17¹3'59", 6369, Horka na Moravou, 220 m, the Nadějná olšina Swamp on the left side of the Mlýnský Brook in the southern part of the Plané loučky Nature Reserve, 1 ex., 18.10.2004, LB, (Beran 2007b); 30 - 49³7'15", 17¹3'58", 6369, Horka na Moravou, $220 \mathrm{~m}$, an alder carr on the left side of the Mlýnský potok Brook in the southern part of the Plané loučky Nature Reserve, 10 ex., 18.10.2004, LB, (Beran 2007b); 31 - 49³7'14", $17^{\circ} 13^{\prime} 51 "$ ", 6369, Horka na Moravou, 220 m, the Pontonová tůn̆ Pool on the right side of the Mlýnský potok Brook in the southern part of the Plané loučky Nature Reserve, 4 ex., 18.10.2004, LB, (Beran 2007b); 32 - 4907'10", 1444'50", 6854, Frahelž, $424 \mathrm{~m}$, shallow (depth about $10 \mathrm{~cm}$ ) Glyceria swamps on the bank of the Rod Pond, 5 ex., 14.5.2006, LB; $33-49^{\circ} 00^{\prime} 12^{\prime \prime}$, 1451'16", 6955, Stříbřec, $442 \mathrm{~m}$, a shallow (depth 10-20 cm) part of the large pool between Nová řeka Canal and Humlenský rybník Pond, 15 ex., 27.10.2005, LB; 34 - 4844'58", 1700'04", 7267 , Tvrdonice, $176 \mathrm{~m}$, a meadow pool on the western edge of Stibůrkovská jezera Nature Reserve, 2 ex., 22.9.2007, LB; 35 - 48 44'47", 1659'51", 7267, Tvrdonice, $176 \mathrm{~m}$, a pool south of the Stibůrkovská jezera Nature Reserve, 10 ex., 22.9.2007, LB; 36 - 4844'45", 1659'46", 7267, Tvrdonice, $176 \mathrm{~m}$, a drain south of the Stibůrkovská jezera Nature Reserve, 5 ex., 22.9.2007, LB; $37-48^{\circ} 44^{\prime} 22^{\prime \prime}, 16^{\circ} 59^{\prime} 35^{\prime \prime}$, 7268, Kostice, 156 $\mathrm{m}$, a shallow (depth $10-25 \mathrm{~cm}$ ) pool connected with canal along the western border of forest to the north-east from Kostice, 17 ex., 10.10.2003, LB; 38 - 48 44'00", 1659'43", 7268, Kostice, $156 \mathrm{~m}$, an oxbow $1,7 \mathrm{~km}$ to the south-east from Kostický rybník Pond, 17 ex., 10.10.2003, LB; 39 - 48 44'21", 16 59'34", 7268 Kostice, $155 \mathrm{~m}$, the first pool at the border of the forest beside the road from Kostice to the Tvrdonické polesí, 10.9.1997, LB and $\mathrm{MH}$, originally published as S. corneum (BERAN \& Horsák 1998); 40 - 48 44'58", $17^{\circ} 00^{\prime} 14 "$, 7268, Tvrdonice, a water ditch (width at the collection site ca. $1 \mathrm{~m}$, depth $0.5 \mathrm{~m}$ ) with nearly stagnating water, a muddy bottom and edges covered with water plants, 30 ex., 20.9.2003, TK.

Appendix 2. Survey of S. nucleus records from the revised museum collections, originally identified as $S$. corneum. Data in the list are as follows: number of the site, code of the mapping grid for faunistic mapping according to PRUNER \& MíKA (1996), name of the nearest settlement, description of the site if provided, number of individuals (ex.), date of investigation, name of investigator (JB - Jaroslav Brabenec; SM - Sylvestr Mácha; CM - Camillo Mell), collection where the voucher specimens can be found (NMP - collection of the National Museum in Prague, the number of the lot is provided in the brackets; SZM - collection of the Silesian Regional Museum in Opava), $+\mathrm{SC}$ indicates the occurrence of $S$. corneum s.str. in the sample.

1 - 5862, Petrovice, a drain in the U Houkvice Nature Reserve, 5 ex., 15.2.1959, JB, NMP (P6M-9819), +SC; 2 - 5860, Březhrad near Hradec Králové, 15 ex., 31.7.1968, JB, NMP (P6M-9824), +SC; 3 - 6373, Suchdol nad Odrou, 1 ex., 22.10.1956, JB, NMP (P6M-9829), +SC; 4-6374, Pustějov, an old branch of the Odra River south of Pustějov, 1 ex., 26.6.1955, SM, NMP (P6M-13 616), 5 ex., SZM, +SC; 5 - 5353, Okřešice near Česká Lípa, a temporary swamp north of the village and west of the pond, 363 ex., 7.1933, 306 ex., 8.1934, 113 ex., VIII.1936, CM, NMP (P6M 16245-7); 6 - 5353, Česká Lípa, a meadow swamp near the factory, 154 ex., 16.4.1939, CM, NMP (P6M 16 250); 7 - 6373, Suchdol nad Odrou, the Dolní les forest in Suchdol, 13 ex., 1.5.1955, SM, SZM; 8-6373, Jeseník nad Odrou, the left side of the Odra river, 30 ex., 14.10.1956, SM, SZM, +SC; 9 - 6177, Louky nad Olší, fish ponds, 15 ex, 12.8.1957 SM, SZM; 10 - 6073, Komárov, drains and wetlands west of Komárov, 18 ex., 19.8.1958, SM, SZM; $11-6274$, Studénka, a drain near the south-west edge of the Kotvice Pond, 30 ex., 12.10.1978, 25 ex. 21.8.1979, 30 ex., 25.V.1979, SM, SZM; 12 - 6274, Studénka, swamps between the Odra River and the Kotvice Pond, 30 ex., 29.8.1978, SM, SZM; 13 - 6374, Bartošovice, swamps in the flood-plain forest south of Horní Bartošovický rybník Pond, 30 ex., 31.8.1978, SM, SZM; 14 - 6174 Jilešovice, wetlands west of the railway station, 17 ex., 13.4.1981, SM, SZM; 15 - 5848, Řevničov, Horní Kracle pond, 8 ex., 21.6.1981, SM, SZM; 16 - 6175, Děhylov, pools south-east of the railway station, $10 \mathrm{ex}$, 7.8.1981, SM, SZM; $17-6175$, Děhylov, a stream above the fish-pond, 8 ex, 7.8.1981, SM, SZM; 18 - 5449, Kostomlaty pod Milešovkou, a peatbog under the Bukový vrch Hill in the Březina Nature Reserve, 14 ex., 29.6.1984, SM, SZM. 